\title{
Traffic Assessment for Unsignalized Intersection Under Influence for Side Friction on Padang Lawas, North Sumatera
}

\author{
Muchammad Zaenal Muttaqin ${ }^{1}$, Desi Yanti Futri Citra Hasibuan ${ }^{1}$ \\ ${ }^{1}$ Civil Engineering, Universitas Islam Riau, Jalan Kaharuddin Nasution 113, Pekanbaru 55292, Indonesia \\ * Corresponding author: muchzaenalmuttaqin@eng.uir.ac.id
}

\section{Article history}

Received: 16.06 .2020

Revised: 12.08 .2020

Accepted: 02.09.2020

DOI:10.31629/jit.v1i2.3165

\begin{abstract}
An unsignalized intersection is a part of a road where currents from different directions or directions meet. There was a conflict between currents from the opposite direction and intersecting each other, resulting in congestion along the arms of the intersection. Likewise, at the intersection of four arms without a signal at Sibuhuan Market, Padang Lawas Regency, North Sumatra, there is a congestion caused by the reduction in the effective width of the road due to parking on the road. At the intersection of four arms without a signal at Sibuhuan Market, Padang Lawas Regency, North Sumatra, there is a congestion caused by side obstacles, a high vehicle population that is not matched by the availability of adequate infrastructure so this research aims to analyze the performance of the four-arm intersection without a signal. based on Indonesian Highway Capacity Manual (MKJI 1997) and analyzes them to improve the performance of these unsignalized intersections. The analysis of the results showed that the intersection performance for the unsigned intersection conditions in the existing condition with the parking on the side of the road which reduced the effective width, the maximum total flow was $2341 \mathrm{pcu} /$ hour, capacity $(\mathrm{C})=2707.06 \mathrm{pcu} /$ hour, and the degree of saturation $(D S)=0.86$, intersection delay $(D)=14.62$ seconds $/$ pcu and queuing opportunity (QP) 30.03 - 59.32\%. Therefore, it is necessary to recalculate with various alternatives so that the DS value meets the requirements of the Indonesian Highway Capacity Manual, which is $<0.75$.
\end{abstract}

Keywords: intersection, degree of saturation, MKJI 1997, Padang Lawas

\section{Introduction}

Roads are land transportation facilities that have an important role in smoothing economic relations and social activity relations, and play a major role in the progress and development of an area. This traffic was very important to increase more about the social mobility for people [1]. Every time people continue to grapple with traffic with various interests [2]. Traffic volume in North Sumatra has been developed to increase more about regional growth and development as well as the rate of population growth. Recently, traffic volume is not accompanied by additional road infrastructure often results in congestion. Traffic congestion was still a major problem in big cities, which is especially felt during rush hours, morning, afternoon and evening [3].

Development of traffic volume in Padang Lawas Regency, especially in the Sibuhuan Market, was still in high congestion rate. This was happened because there is a market which is a trading center right on Jl. Sibuhuan-Gunung Tua and Jl. Prof. H. M Yamin SH with high side friction [4]. This is due to market activity, vehicles parked on the road and vehicles in and out of the intersection lane [5]. 
From the above problems, it can be concluded that the intersection with no signal at the Sibuhuan Market needs to be evaluated and analyzed both on the performance of traffic management, road widening, the existing condition from an unsigned intersection to a signalized intersection to be able to solve existing problems optimally [6].

The purpose of this study was determining about performance of existing traffic at the intersection at the Sibuhuan Market, Padang Lawas Regency, North Sumatra. It is necessary to define the problem, namely the research was carried out at the intersection of Sibuhuan Market, Padang Lawas Regency, North Sumatra. This study was divided into 3 (three) sessions for peak hours, namely 06.0008.00 WIB, 12.00-14.00 WIB, and 16.00-18.00 WIB for two working days (Monday and Tuesday) and Saturday for the weekend.

\section{Theoretical Background}

Basically, in conducting research on an object it is important to understand the mindset of the research to be carried out. The mindset will help direct the research to be carried out. The compilation in this research focuses on the volume of traffic flow that passes through the intersection of the intersection of Sibuhuan Market, Padang Lawas Regency, North Sumatra, population data of Padang Lawas Regency, and measures the intersection arm and looks at the condition of the intersection.

This study used a field observation method, namely the main survey by means of manual recording per 2 (two) hours and by direct measurement using a meter to obtain the intersection arm width and parking width, then analyzed the data obtained. The survey was carried out on working days, namely Monday and last Tuesday on a nonworking day, namely Saturday, with the consideration that these days represent peak hours and the traffic volume is expected to differ greatly. Another very influential consideration is the research location which is the most visited trade area, especially on weekdays. The research location is an unsigned intersection with 4 (four) arms without a median, which is then carried out by observation for 3 (three) sessions for 2 (two) hours, namely 06.00-08.00 WIB, proceed to the next session at 12.00-14.00 WIB, and the last session 16.00-18.00 WIB, observations made at 5 minutes intervals.
The input variables for the width of the approach and the type of intersection can be seen in Tables 1 and 2 , as follows.

Table lanes and the average

\begin{tabular}{|c|c|}
\hline $\begin{array}{c}\text { width of the minor and } \\
\text { main approaches } \mathrm{W}_{\mathrm{AC}} \\
\text { and } \mathrm{W}_{\mathrm{BD}}\end{array}$ & $\begin{array}{c}\text { Number of lanes } \\
\text { (total for two } \\
\text { directions) }\end{array}$ \\
\hline $\begin{array}{c}\mathrm{WB}_{\mathrm{BD}}=(\mathrm{b}+\mathrm{d} / 2) / 2 \\
<5.5\end{array}$ & 2 \\
$\geq 5.5$ & 4 \\
\hline $\mathrm{WB}_{\mathrm{AC}}=(\mathrm{a} / 2+\mathrm{c} / 2) /$ & 2 \\
$2<5.5$ & 4 \\
$\geq 5.5$ & \\
\hline
\end{tabular}

Table 2. Intersection Type

\begin{tabular}{|c|c|c|c|}
\hline $\begin{array}{c}\text { IT } \\
\text { Code }\end{array}$ & $\begin{array}{c}\text { Number of } \\
\text { intersection } \\
\text { arms }\end{array}$ & $\begin{array}{c}\text { Number } \\
\text { of minor }\end{array}$ & $\begin{array}{c}\text { lane lanes } \\
\text { Number } \\
\text { of minor } \\
\text { road lanes }\end{array}$ \\
\hline 322 & 3 & 2 & 2 \\
\hline 324 & 3 & 2 & 4 \\
\hline 342 & 3 & 4 & 2 \\
\hline 422 & 4 & 2 & 2 \\
\hline 424 & 4 & 2 & 4 \\
\hline
\end{tabular}

\subsection{Capacity $(C)$}

Value of basic capacity $\left(\mathrm{C}_{\mathrm{o}}\right)$ can be seen based on the type of intersection contained in Table 3. as follows,

Table 3.Basic Capacity $\left(\mathrm{C}_{\mathrm{o}}\right)$

\begin{tabular}{|c|c|}
\hline IT Junction Type & Basic Capacity (pcu / hour) \\
\hline 322 & 2700 \\
\hline 342 & 2900 \\
\hline 324 or 344 & 3200 \\
\hline 422 & 2900 \\
\hline 424 or 444 & 3400 \\
\hline
\end{tabular}

Ways Calculation of Capacity (C) can be calculated with the provisions of MKJI 1997 with the formula of Capacity (C) as follows:

$\mathrm{C}=\mathrm{C}_{\mathrm{O}} \times \mathrm{F}_{\mathrm{W}} \times \mathrm{F}_{\mathrm{M}} \times \mathrm{F}_{\mathrm{CS}} \times \mathrm{F}_{\mathrm{RSU}} \times \mathrm{F}_{\mathrm{LT}} \times \mathrm{F}_{\mathrm{RT}} \times \mathrm{F}_{\mathrm{MI}}$

Description :

$\mathrm{C}$ = Capacity (pcu / hour)

$\mathrm{C}_{\mathrm{o}}=$ Basic capacity (pcu / hour)

$\mathrm{F}_{\mathrm{W}}=$ Approach width adjustment factor

$\mathrm{F}_{\mathrm{M}}=$ Main road median adjustment factor

$\mathrm{F}_{\mathrm{CS}}=$ City size adjustment factor 
$\mathrm{F}_{\mathrm{RSU}}=\mathrm{Road}$ environment type adjustment factor, side friction and nonmotorized vehicles

$\mathrm{F}_{\mathrm{LT}}=$ Left turn adjustment factor

$\mathrm{F}_{\mathrm{RT}}=$ Right turn adjustment factor

$\mathrm{F}_{\mathrm{MI}}=$ minor road current adjustment

\section{factor 2.2 Adjustment factor}

a. Approach width adjustment factor $\left(\mathrm{F}_{\mathrm{W}}\right)$

Approach width adjustment factor $\left(\mathrm{F}_{\mathrm{W}}\right)$ is calculated based on the type of intersection, using equation (2), as follows:

$\mathrm{F}_{\mathrm{W}}=0.70+0.0698 \mathrm{~W}_{1}$

Description:

$\mathrm{F}_{\mathrm{W}}=$ Approach width adjustment factor

$\mathrm{W}_{1}=$ Average width of approach $(\mathrm{m})$

Input variables for the main road median type are shown in Table 4, for city size adjustment factors are listed in Table 5 and for adjustment factors for road environment type, side obstacles, and vehicles Nonmotorized is shown in Table 6, below:

Table 4. Main road median adjustment factor

\begin{tabular}{|c|c|c|}
\hline Description & Type $\mathrm{M}$ & $\begin{array}{c}\text { Adjustment factor } \\
\text { Main road median } \\
\left(\mathrm{F}_{\mathrm{M}}\right)\end{array}$ \\
\hline $\begin{array}{c}\text { No main road } \\
\text { median }\end{array}$ & None & 1.00 \\
\hline $\begin{array}{c}\text { There is a main } \\
\text { road median, } \\
\text { width }<3 \mathrm{~m}\end{array}$ & Yes & 1,05 \\
\hline $\begin{array}{c}\text { There is a median of } \\
\text { the main road, width } \\
\geq 3 \mathrm{~m}\end{array}$ & There is & 1.20 \\
\hline
\end{tabular}

Table 5. Adjustment factor for City Size City

\begin{tabular}{|c|c|c|}
\hline Size $(\mathrm{CS})$ & $\begin{array}{c}\text { Population } \\
\text { (million) }\end{array}$ & $\begin{array}{c}\text { Adjustment factor } \\
\text { for City Size }\left(\mathrm{F}_{\mathrm{CS}}\right)\end{array}$ \\
\hline Very Small & $<0.1$ & 0.82 \\
\hline Small & $0,1-0.5$ & 0.88 \\
\hline Medium & $0.5-1.0$ & 0.94 \\
\hline Large & $1.0-3.0$ & 1.00 \\
\hline Very large & $>3.0$ & 1.05 \\
\hline
\end{tabular}

Table 6. Adjustment factors for road environment types, side barriers and non-motorized vehicles

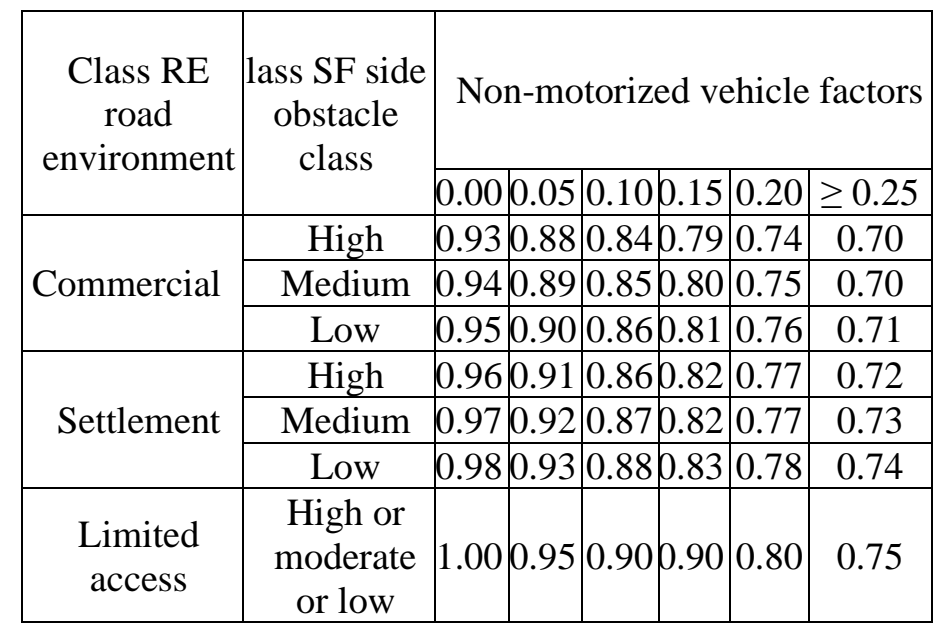

b. Left Turn Adjustment Factor $\left(\mathrm{F}_{\mathrm{LT}}\right)$

The left turn adjustment factor $\left(\mathrm{F}_{\mathrm{LT}}\right)$ is calculated using equation (3), as follows:

$\mathrm{F}_{\mathrm{LT}}=0.84+1.61 \mathrm{P}_{\mathrm{LT}}$

Where:

$\mathrm{F}_{\mathrm{LT}}=$ left turn adjustment factor

$\mathrm{P}_{\mathrm{LT}}=$ Ratio of left turning current

c. Right turn adjustment factor $\left(\mathrm{F}_{\mathrm{RT}}\right)$

The right turn adjustment factor $\left(\mathrm{F}_{\mathrm{RT}}\right)$ is determined based on the number of intersection arms, where the number of intersection arms in the research is 4 arms, then it is calculated using equation (4), as follows:

$\mathrm{F}_{\mathrm{RT}}=1.00$

d. Minor road ratio adjustment factor $\left(\mathrm{F}_{\mathrm{MI}}\right)$

Minor road ratio adjustment factor $\left(\mathrm{F}_{\mathrm{MI}}\right)$ is influenced by the type of intersection, where the type of intersection used is 422 then it is calculated using equation (5), as follows:

$\mathrm{F}_{\mathrm{MI}}=1.19 \times \mathrm{P}_{\mathrm{MI}^{2}}-1.19 \times \mathrm{P}_{\mathrm{MI}}+1.19$

Where:

$\mathrm{F}_{\mathrm{MI}}=$ minor road adjustment factor

$\mathrm{P}_{\mathrm{MI}}=$ Right turning current ratio

\subsection{Degree of Saturation (DS)}

Value of DS (Degree Of Saturation) is obtained by comparing traffic flows total $\left(\mathrm{Q}_{\mathrm{TOT}}\right)$ with Capacity

(C) using equation (6), as follows:

$\mathrm{DS}=\mathrm{Q}_{\mathrm{TOT}} / \mathrm{C}$ 


\subsection{Delay}

a. The intersection traffic delay $\left(\mathrm{DT}_{\mathrm{I}}\right)$

is the average traffic delay for all motorized vehicles entering the intersection. The intersection traffic delay $\left(\mathrm{DT}_{\mathrm{I}}\right)$ is calculated using the following equation (7):

$\mathrm{DT}_{\mathrm{I}}=\left(\frac{1.0504}{0.2742-0.2042 D S}\right)-(1-D S) \times 2$

b. Main road traffic delay (DT $\left.\mathrm{MA}_{\mathrm{MA}}\right)$

Main road traffic delay (DT $\mathrm{DA}_{\mathrm{MA}}$ ) is calculated using the following equation (8):

$\mathrm{DT}_{\mathrm{MA}}=\left(\frac{1.05034}{0.346-0.246 D S}\right)-(1-D S) \times 1.8$

c. Minor road traffic delays (DT $\left.\mathrm{DI}_{\mathrm{M}}\right)$

Minor road traffic delays (DT $\left.{ }_{\mathrm{MI}}\right)$ are calculated using equation (9), as follows:

$\mathrm{DT}_{\mathrm{MI}}=\left(\mathrm{Q}_{\mathrm{TOT}} \times \mathrm{DT}_{\mathrm{I}}-\mathrm{Q}_{\mathrm{MA}} \times \mathrm{DT}_{\mathrm{MA}}\right) / \mathrm{Q}_{\mathrm{MI}}$

Where:

$\mathrm{Q}_{\mathrm{MA}}=$ Total traffic flow of major roads

$\mathrm{Q}_{\mathrm{MI}}=$ Total traffic flow of minor roads

\section{d. Intersection geometric delay (DG)}

Intersection geometric delay (DG) includes DS and total turning ratio $\left(\mathrm{P}_{\mathrm{T}}\right)$. Thus, equation (10) is used, as follows;

$\mathrm{DG}=(1-\mathrm{DS}) \times\left(\rho_{\mathrm{T}} \times 6+\left(1-\rho_{\mathrm{T}}\right) \times 3+\mathrm{DS} \times 4(\mathrm{sec} / \mathrm{pcu})\right.$ (10)

\section{e. Junction delay (D)}

Junction delay (D) is the total delay due to traffic volume and road geometric, where the intersection delay is calculated using equation (11), as follows:

$\mathrm{D}=\mathrm{DG}+\mathrm{DT}_{\mathrm{I}}$

\section{f. Queue Chances}

The queue probability range is determined from the empirical relationship between the queue probability and the degree of saturation, for more details can be seen in Figure (1) or equations (12) and (13), as follows.

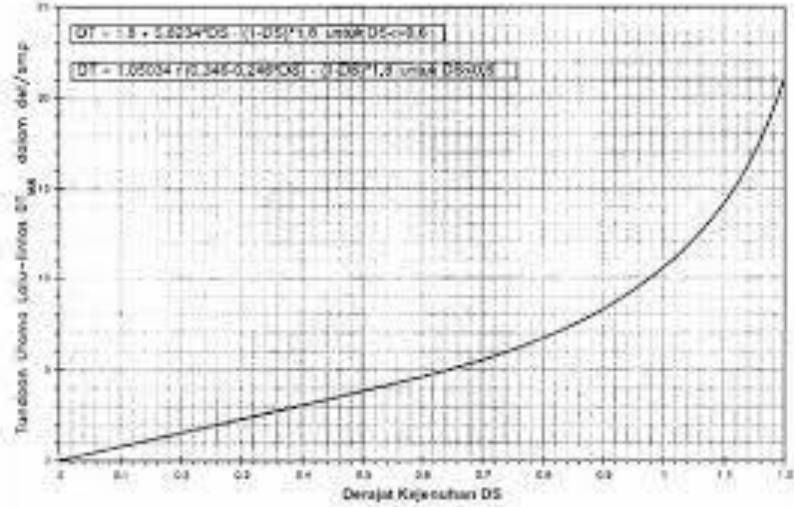

Figure 1. Queue Chance Range (QP\%)

$\mathrm{QP} \%_{\text {Upper limit }}=47.71 \mathrm{DS}-24.68 \mathrm{DS}^{2}+56.47 \mathrm{DS}^{3}$ (12)

$\mathrm{QP} \%$ Lower limit $=9,02 \mathrm{DS}-20,66 \mathrm{DS}^{2}+10,49 \mathrm{DS}^{3}$

\section{Methodology}

\subsection{Procedure}

a. Primary Data Collection Primary

data is data obtained from the research location.

How to get primary data by means of manual recording per 2 hours and by direct measurement using a meter to get the intersection arm width and parking width, then analyzed the data obtained. The survey was conducted on weekdays, namely Monday and last Tuesday on a non-working day, namely Saturday, taking into account that these days represent peak hours and the estimated traffic volume is significantly different. Another very influential consideration is that the research location is a trade and shopping center area which is still widely passed and visited, especially during working hours. The research location is an unsigned intersection with four arms, namely Jl. `SibuhuanGunung Tuan (North), Jl. Surapati (South), Jl. Kihajar Dewantara (East) and Jl. Prof. H. M Yamin SH (West). Then the observations were made for 3 (three) diving sessions per 2 hours, namely 06.0008.00 WIB, 12.00-14.00 WIB, and the last session 16.00-18.00 WIB. Observations were made at 5 minutes intervals, and produced traffic volume data.

\section{b. Secondary Data Collection}

According to Hasan (2002: 58) secondary data is data obtained by researchers from existing sources or from previous data. This data is used to support the primary data that has been obtained, namely, 
from library materials, literature, previous research, books and so on. Secondary data consists of:

1) Location Map, which determines the layout where the research will be carried out.

2) Geometric intersection, which measures the width of the intersection arm of the

3) Population Data, namely to determine the size class of the city of Padang Lawas Regency, North Sumatra from the relevant agency, such as: BPS (Central Statistics Agency)

4) Environmental conditions, namely determining the type of road environment based on the side friction classification in Table 6.

\section{Results and Discussion}

\subsection{Intersection Geometric Results}

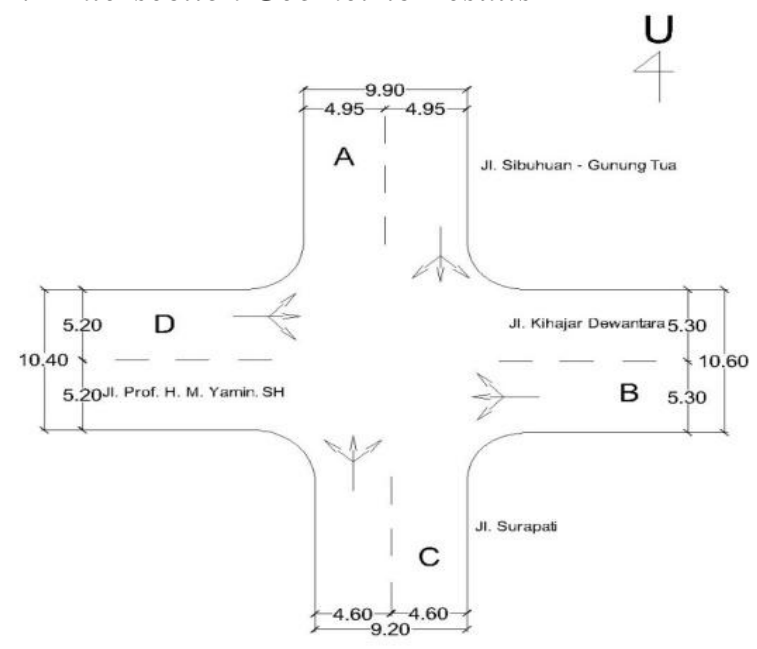

Figure 3. Location Plan

The geometric intersection results are obtained directly from observations and measurements in the field, namely the intersection of four sibuhuan markets. Observations during the survey found that the intersection of the Sibuhuan Market was the intersection of Jl. Kihajar Dewantara - Jl. Prof. H. M Yamin SH as the main road, and Jl. SibuhuanGunung Tua - Jl. Surapati as a minor path. This intersection has 4 arms and each arm 2 lanes and 2 lanes without a median.

The width of the main roads are $10.60 \mathrm{~m}$ (East Arm) and $10.40 \mathrm{~m}$ (West Arm), while those on minor roads are $9.90 \mathrm{~m}$ (North Arm) and $9.20 \mathrm{~m}$ (South Arm).

\subsection{Traffic}

Volume The volume of traffic flowing through the Sibuhuan Market is observed 2 (two) days on weekdays (Monday and Tuesday) and 1 (one) nonworking day (Saturday) with 3 (three) sessions, namely, 06.00-08.00 WIB, 12.00-14.00 WIB and 16.00-18.00 WIB, the maximum traffic volume results are on Tuesday at 12.00-14.00 WIB with a traffic volume value of $2341 \mathrm{pcu} /$ hour. For more details can be seen in Table 7, as follows:

Table 7. Summary of Traffic Flow Volume

\begin{tabular}{|c|c|c|}
\hline Day & Period & $\begin{array}{l}\text { Volume of traffic flow } \\
\text { (smp / hour) }\end{array}$ \\
\hline \multirow{3}{*}{ Mon } & $06.00-08.00$ & 2315 \\
\hline & $12.00-14.00$ & 2341 \\
\hline & $16.00-18.00$ & 2328 \\
\hline \multirow{3}{*}{$\begin{array}{c}\text { Tuesda } \\
\mathrm{y}\end{array}$} & $\begin{array}{ll}06: 00 & \text { to } \\
08: 00 & \end{array}$ & 2298 \\
\hline & $12: 00-14.00$ & 2333 \\
\hline & $16.00-18.00$ & 2311 \\
\hline \multirow{3}{*}{$\begin{array}{c}\text { Saturda } \\
\mathrm{y}\end{array}$} & $06.00-08.00$ & 2278 \\
\hline & $12.00-14.00$ & 2209 \\
\hline & $16.00-18.00$ & 2220 \\
\hline
\end{tabular}

\subsection{Analysis of Simpang Not signalized \\ Data Input}

a. $\mathrm{Q}_{\mathrm{MI}}$ is the sum of all traffic on minor roads, which are known to the current total of 1048 minor road smp / hour .

b. $\mathrm{Q}_{\mathrm{MA}}$ is the total traffic flow on the major road, which is known to be the total flow of minor roads as $1294 \mathrm{pcu} /$ hour.

c. $\mathrm{P}_{\mathrm{MI}}$ is the minor road current divided by the total current $\left(\mathrm{Q}_{\text {Tот }}\right)$, where the total current is $2341 \mathrm{pcu}$ / hour. So, the Pvalue is obtained $\mathrm{MI}_{\mathrm{MI}}$ as follows:

$\mathrm{P}_{\mathrm{MI}}=\frac{Q_{M I}}{Q_{T O T}}=\frac{1048}{2341}=0.45$

d. $P_{\mathrm{LT}}$ Pand $_{\mathrm{RT}}$ obtained from the current total turn left $\left(\mathrm{P}_{\mathrm{LT}}=783 \mathrm{smp} /\right.$ hour and the flow right turn total total $\left(\mathrm{P}_{\mathrm{RT}}\right)=766 \mathrm{smp} /$ hour

$$
\begin{gathered}
\mathrm{P}_{\mathrm{LT}}=\frac{Q_{L T}}{Q_{T O T}}=\frac{783}{2341}=0.33 \mathrm{smp} / \text { hour } \\
\mathrm{P}_{\mathrm{RT}}=\frac{Q_{R T}}{Q_{T O T}}=\frac{766}{2341}=0.33 \mathrm{pcu} / \text { hour }
\end{gathered}
$$

e. Ratio between non-motorized vehicle flows

$\mathrm{P}_{\mathrm{UM}}=\frac{Q_{U M}}{Q_{T O T}}=0.11$ vehicles $/$ hour 


\subsection{Traffic Flow Analysis iIntest Unsignalized Intersection Capacity}

a. Approach width $\left(\mathrm{W}_{1}\right)$ and intersection type (IT)

1) Average width of the minor and major approaches $\mathrm{W}_{\mathrm{AC}}$ and $\mathrm{W}_{\mathrm{BD}}$ and average width of the approximation $\mathrm{W}_{1}$

North Approach $\left(\mathrm{W}_{\mathrm{A}}\right)=(\mathrm{a}-$ parking width $) / 2$

$$
=(9.90-2.00) / 2
$$

$$
=3.95 \mathrm{~m}
$$

South Approach $\left(\mathrm{W}_{\mathrm{C}}\right)=(\mathrm{a}-$ parking width $) / 2$

$$
=(9,20-2.00) / 2
$$

$$
=3.60 \mathrm{~m}
$$

East Approach $\left(\mathrm{W}_{\mathrm{B}}\right)=(\mathrm{a}-$ parking width $) / 2$

$$
\begin{aligned}
& =(10.60-2.30) / 2 \\
& =4.15 \mathrm{~m}
\end{aligned}
$$

West Approach $\left(\mathrm{W}_{\mathrm{D}}\right)=(\mathrm{a}-$ parking width $) / 2$

$$
\begin{aligned}
& =(10.40-2.20) / 2 \\
& =4.10 \mathrm{~m}
\end{aligned}
$$

Width of minor approach $\left(\mathrm{W}_{\mathrm{AC}}\right)$

$$
\begin{aligned}
& =\left(\mathrm{W}_{\mathrm{A}}+\mathrm{W}_{\mathrm{C}}\right) / 2 \\
& =(3.95+3.60) / 2 \\
& =3.78 \mathrm{~m}
\end{aligned}
$$

Width of the minor approach $\left(\mathrm{W}_{\mathrm{BD}}\right)$

$$
\begin{aligned}
& =\left(\mathrm{W}_{\mathrm{A}}+\mathrm{W}_{\mathrm{C}}\right) / 2 \\
& =(4.15+4.10) / 2 \\
& =4.13 \mathrm{~m}
\end{aligned}
$$

Width of the minor approach $\left(\mathrm{W}_{\mathrm{BD}}\right)$

$$
\begin{aligned}
& =\left(\mathrm{W}_{\mathrm{A}}+\mathrm{W}_{\mathrm{C}}\right) / 2 \\
& =(4.15+4.10) / 2 \\
& =4.13 \mathrm{~m}
\end{aligned}
$$

Average width of the approximation $\left(\mathrm{W}_{\mathrm{BD}}\right)$

$$
\begin{aligned}
& =\left(\mathrm{W}_{\mathrm{A}}+\mathrm{WB}+\mathrm{W}_{\mathrm{C}}+\mathrm{W}_{\mathrm{D}}\right) / 4 \\
& =(3.95+3.60+4.15+4.10) / 4 \\
& =4.13 \mathrm{~m}
\end{aligned}
$$

Number of lanes

$\mathrm{W}_{\mathrm{AC}}=2$ lanes

$\mathrm{W}_{\mathrm{BD}}=2$ lanes

Intersection Type

From the table it is found that the type of intersection is 422

2) Capacity Basic $\left(\mathrm{C}_{\mathrm{o}}\right)$

The intersection type is 422 , then the basic capacity is $2900 \mathrm{pcu} /$ hour.

3) Approach width adjustment factor $\left(\mathrm{F}_{\mathrm{W}}\right)$

$$
\begin{aligned}
& \mathrm{F}_{\mathrm{W}}=0.70+0.0698 \mathrm{~W}_{1} \\
& \mathrm{~F}_{\mathrm{W}}=0.70+0.0698(4,13 \mathrm{~m}) \\
& \mathrm{F}_{\mathrm{W}}=1.04 \mathrm{~m}
\end{aligned}
$$

4) Main road median adjustment factor $\left(F_{M}\right)$
At the study location there is no good median i tu on the main road and minor roads. $\left(\mathrm{F}_{\mathrm{M}}\right)=1.00$

5) City size adjustment factor $\left(\mathrm{F}_{\mathrm{CS}}\right)$

Total population of Padang Lawas district $=$ 281,239 people, which means small size, so that the value of the city size adjustment factor $\left(\mathrm{F}_{\mathrm{CS}}\right)$ $=0.88$

6) . side friction, and non-motorized vehicles ( $\left.F_{\text {RSU }}\right)$

$$
\begin{aligned}
& \text { RE = Commercial } \\
& \text { SF =height } \\
& \text { PUM }=0.83
\end{aligned}
$$

7) Left turn adjustment factor $\left(\mathrm{F}_{\mathrm{LT}}\right)$

$$
\begin{aligned}
\mathrm{F}_{\mathrm{LT}} & =0.84+1.61 \mathrm{P}_{\mathrm{LT}} \\
& =0.84+1.61(0.33)=1.38
\end{aligned}
$$

8) Right turn adjustment factor $\left(\mathrm{F}_{\mathrm{RT}}\right)$ $\mathrm{F}_{\mathrm{RT}}=1,00$

9) Minor road current adjustment factor $\left(\mathrm{F}_{\mathrm{MI}}\right)$

$$
F_{M I}=\left(1.19 \times 0.45^{2}\right)-(1.19 \times 0.45) 1.19
$$$$
=0.89
$$

10) Capacity (C)

$$
\begin{aligned}
\mathrm{C}= & \mathrm{C}_{\mathrm{o}} \times \mathrm{F}_{\mathrm{W}} \times \mathrm{F}_{\mathrm{M}} \times \mathrm{F}_{\mathrm{CS}} \times \mathrm{F}_{\mathrm{RSU}} \times \mathrm{F}_{\mathrm{LT}} \times \mathrm{F}_{\mathrm{RT}} \times \mathrm{F}_{\mathrm{MI}} \\
= & 2900 \times 1.04 \times 1 \times 0.88 \times 0.83 \times 1.38 \times 1 \times \\
& 0.89 \\
= & 2711 \mathrm{pcu} / \text { hour }
\end{aligned}
$$

\subsection{Traffic Behavior}

a. Degree of Saturation (DS)

$$
\mathrm{DS}=\frac{Q_{T O T}}{C}=\frac{2341}{2711}=0.86
$$

(degree of saturation $>0.75$ )

b. Delay $\left(\mathrm{DT}_{1}\right)$

$$
\begin{aligned}
\mathrm{DT}_{\mathrm{I}} & =\left(\frac{1.0504}{0.2742-0.2042 D S}\right)-(1-D S) \times 2 \\
\mathrm{DT}_{\mathrm{I}} & =\left(\frac{1.0504}{0.2742-0.2042 \times 0.86}\right)-(1-0.86) \times 2 \\
& =10.49 \mathrm{sec} / \mathrm{pcu}
\end{aligned}
$$

c. Main Road Traffic Delay (DT $\mathrm{DA}_{\mathrm{MA}}$ )

$$
\begin{aligned}
\mathrm{DT}_{\mathrm{MA}} & =\left(\frac{1.05034}{0.346-0.246 D S}\right)-(1-D S) \times 1.8 \\
\mathrm{DT}_{\mathrm{MA}} & =\left(\frac{1.05034}{0.346-0.246 \times 0.86}\right)-(1-0.86) \times 1.8 \\
& =7.64 \mathrm{sec} / \mathrm{pcu}
\end{aligned}
$$

d. Minor Road Traffic Delay (DT $\left.\mathrm{Mi}_{\mathrm{Mi}}\right)$

$$
\begin{aligned}
\mathrm{DT}_{\mathrm{MI}} & =\left(\mathrm{Q}_{\text {Tот }} \times \mathrm{DT}_{\mathrm{I}}-\mathrm{Q}_{\text {MA }} \times \mathrm{DT}_{\mathrm{MA}}\right) / \mathrm{Q}_{\text {MI }} \\
\mathrm{DT}_{\mathrm{MI}} & =(2341 \times 10,49-1294 \times 7.64) / 1048 \\
& =14.01 \mathrm{sec} / \mathrm{pcu}
\end{aligned}
$$

e. Geometric Delay Intersection (DG)

$$
\begin{aligned}
\mathrm{DG} & =(1-\mathrm{DS}) \times\left(\rho_{\mathrm{H}} \times 6+\left(1-\rho_{\mathrm{H}}\right) \times 3+\mathrm{DS} \times 4\right. \\
\mathrm{DG} & =(1-0.86) \times(0.66 \times 6)+(1-0.66) \times 3+0.86 \times 4 \\
& =4.13 \mathrm{sec} / \mathrm{pcu}
\end{aligned}
$$


f. Intersection Delay (D)

$\mathrm{D}=\mathrm{DG}+\mathrm{DT}_{1}$

$\mathrm{D}=4.13+10.46$

$\mathrm{D}=14.59 \mathrm{sec} / \mathrm{pcu}$

g. Chance of Queuing $(\mathrm{QP} \%)$

$$
\begin{aligned}
\mathrm{QP} \%{ }_{\text {вА }}= & 47,71 \mathrm{DS}-24.68 \mathrm{DS}^{2}+56,47 \mathrm{DS}^{3} \\
= & 47.71(0.86)-24.68(0.86)+56.47 \\
& \left(0.86^{3}\right) \\
= & 30.03 \% \\
\mathrm{QP} \% \text { в }= & 9,20 \mathrm{DS}-20.66 \mathrm{DS}^{2}+10,49 \mathrm{DS}^{3} \\
= & 9.20(0.86)-20.66(0.86)+56.47\left(0.86^{3}\right) \\
= & 59.32 \% .
\end{aligned}
$$

\section{Conclusion}

Based on the results of the research conducted, it can be concluded that there is no signaling intersection of Sibuhuan Market. experiencing a peak traffic flow on a weekday, namely 12.00-14.00 hours with a traffic volume of $2341 \mathrm{pcu} /$ hour. This intersection has 4 (four) arms with a capacity (C) of an intersection of $2707.06 \mathrm{pcu} /$ hour, a degree of saturation (DS) of 0.86 with a service level of $\mathrm{C}$, an intersection delay of $14.62 \mathrm{sec} / \mathrm{pcu}$, and a queue opportunity (QP) $30.03 \%-59.32 \%$.

\section{References}

[1] Amtoro, Rif Arbima, "Analysis of the Four-Arm Signalless Intersection (Case Study of the FourArmed Intersection of Jalan Wates Km. 5, Gamping, Sleman, Yogyakarta)", Journal of Civil Engineering, Indonesian Islamic University, 2015.

[2] Ari, Ramadhan Muhammad, Purwanto and Sahrullah, "Analysis of Unsignalized Intersection Traffic Flow (Case Study at the Intersection of Jl. Untung Suropati - Jl. Ir. Sutami - Jl. Selamet Riyadi in Samarinda City)," Journal of Civil Engineering, University of 17 August 1945, 2015.

[3] Budiman, Arif et al, "Analysis of Unsignalized Intersections at the Boru City Intersection of Serang," Civil Engineering Journal, Sultan Ageng Tirtayasa University, 2016.
[4] Department of Public Works, Directorate General of Highways, "Indonesian Highway Capacity Manual (MKJI)," 1997.

[5] Juniardi, " Analysis of Traffic Flow at Unsignalized Intersections (Case Study: Timoho and Tunjung Simpang Tunjung in Yogyakarta City), "Civil Engineering Master's Thesis, Diponegoro University Semarang, 2006.

[6] Khisty, JC and Lall KB, Basics of Transporta Engineering si Volume I, Jakarta, 2005.

[7] Listiana, Novi and Tri Subdiyo, "Analysis of Unsignalized Intersections on Jalan Raya DramagaBabulak Bogor, West Java," Jsil Journal of Civil and Environmental Engineering, Vol. 04, No. 01, 69 - 75, April 2019.

[8] Munawar, A., Urban Road Traffic Management, 2004.

[9] Putra, Tilarso Mada, "Performance Analysis of Unsignalized Intersection and Purwosari Roundabout," Civil Engineering Scientific Publications, Muhammadiyah University of Surakarta, 2017.

[10] Putra, AS, "Analysis of the Impact of Urban Transport Ngetem Activities on Traffic Performance at the Laladon Intersection, Bogor, Thesis, Bogor Agricultural University, 2016.

[11] Rorong, Noviryadi, Lintong Elisabeth, and Joice E. Wanni," Performance Analysis of Unsignalized Intersections at Jalan S . Parman and Jalan Di Panjaitan, "Journal of Civil Statics Vol. 3, No. 11, 747 - 758, November 2015.

[12] Saleh, Pandu Abraham, "Analysis and Alternative Traffic Solutions at the Roundabout of Jalan Teuku Umar Denpasar", Journal of Civil Engineering Works, Volume 4, Number 4, 415 - 427, 2015.

[13] Sugihari, Pristiwa and Wahyu Widodo, "Performance Analysis of Unsignalized Intersection (Case Study: Unsignalized Intersection 3 Jl. Raya Seturan - Jl. Raya Babarsari - Jl. Kledokan, Depok, Sleman, Yogyakarta)." Civil Engineering Journal, Muhammadiyah University of Yogyakarta, 2013.

[14] Wikrama, AANA Jaya, "Performance Analysis of Unsigned Intersection (Case Study of Jalan Teuku Umar Barat - Jalan Gunung Salak)," Civil Engineering Scientific Journal, Vol. 15, No. 1, 58 71, November 2011.

[15] Wikrama, AANgr. Agung Jaya, "Unsignalized Intersection Study (Case Study; Jalan Raya Uluwatu - Jalan Raya Kampus Unud)", Report of Civil Engineering Study Program, Univ. Udayana, 2017.

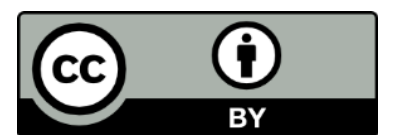

This is an open-access article distributed under the terms of the Creative Commons Attribution 4.0 International License (CC-BY). 